\title{
ADDITION OF EGBE AND ETHANOL TO ENHANCE MES PERFORMANCE AS CHEMICAL FLOODING MATERIAL
}

\author{
Dewi Tristantini*, Humala Paulus Halim, Muhammad Faldy Zuliardy \\ Chemical Engineering Department, Faculty of Engineering \\ University of Indonesia \\ Kampus Baru UI Depok, Depok 16424 \\ Email:detris@che.ui.ac.id
}

\begin{abstract}
Methyl ester sulfonate (MES) performance as chemical flooding material for EOR was investigated by adding emulsifier ethyl glycol mono butyl ether (EGBE) and ethanol. MES had interfacial tension (IFT) value as low as $10^{-3}$ dyne $/ \mathrm{cm}$, but its disadvantage was low solubility in brine water. Repairing this nature, MES was modified by adding nonyl phenol ethoxylate (Tergitol, as secondary surfactant), EGBE and ethanol. The mixed surfactant was tested for IFT value, solubility, and thermal influence to IFT value in various concentrations. The result indicated a significant effect of emulsifier concentration to IFT value. The longer carbon chains, the easier micelle interaction was formed. The positive effects to solubility were caused by the polarity of long chain EGBE and the increase of micro emulsion stability by ethanol. The best formulas were $1 \%$ concentration surfactant in brine water consist of MES $40 \%$, Tergitol $20 \%$, ethanol $40 \%$ and $0.3 \%$ of MES $40 \%$, Tergitol $20 \%$, EGBE $40 \%$. These formulas also had better solubility than MES alone, since they only form one phase. Heat treatment at $62.5{ }^{\circ} \mathrm{C}$ for 1 day caused lower IFT because of increasing interaction between emulsifier and micelle. Further heating resulted in a higher IFT as the emulsifier structure collapsed, which made interactions difficult to achieve.
\end{abstract}

Keywords: EOR, interfacial tension, methyl ester sulfonate, non-ionic, surfactant

\begin{abstract}
Abstrak
Kinerja metil ester sulfonat (MES) sebagai bahan chemical flooding untuk EOR telah dilakukan dengan menambahkan pengemulsi etil glikol mono butil eter (EGBE) dan etanol. MES memiliki nilai tegangan permukaan (IFT) sebesar $10^{-3}$ dyne/cm, tetapi memiliki kelarutan yang rendah dalam air formasi. Untuk memperbaiki sifat ini, MES ditambahkan dengannonyl phenol ethoxylate (Tergitol) sebagai surfaktan kedua, EGBE dan etanol. Hasil formulasi surfaktan diuji nilai IFT, kelarutan dan pengaruh termal terhadap nilai IFT dalam berbagai tingkat konsentrasi. Hasil pengujian mengindikasikan adanya pengaruh konsentrasi pengemulsi yang besar terhadap nilai IFT. Rantai karbon yang lebih panjang berakibat semakin mudah interaksi micelle terjadi. Kelarutan yang semakin tinggi disebabkan polaritas dari rantai panjang EGBE dan meningkatnya stabilitas mikroemulsi oleh alkohol. Hasil formulasi terbaik didapatkan pada konsentrasi surfaktan 1\% dengan MES 40\%, Tergitol 20\%, Alkohol 40\% dan konsentrasi surfaktan 0,3\% dengan MES 40\%, Tergitol 20\%, EGBE 40\%. Formula ini memiliki kelarutan yang lebih baik daripada MES karena hanya membentuk 1 fase. Pengaruh pemanasan 62,5 ${ }^{\circ} \mathrm{C}$ selama 1 hari menyebabkan IFT semakin rendah karena meningkatnya interaksi antara pengemulsi dan micelle. Pemanasan yang berlebihan menyebabkan IFT naik karena rusaknya struktur pengemulsi sehingga interaksi sulit terjadi.
\end{abstract}

Kata kunci: EOR, metil ester sulfonat, non-ionik, surfaktan, tegangan permukaan

*corresponding author 


\section{Introduction}

Energy consumption rate in Indonesia is increasing. One of the solutions that can be applied is surfactant flooding technology to produce residual oil in Indonesian reservoir, so the petroleum production rate will be increased. Enhanced Oil Recovery (EOR) by surfactant flooding has become a solution in recent years. A new surfactant has been developed from bio-based material to replace previous surfactants. This surfactant is the methyl ester sulfonate (MES), which is synthesized from palm oil (Hambali et al., 2008).

In the EOR process, low interfacial tension at low surfactant concentrations is considered to be an important parameter in optimizing chemical systems for recovering trapped oil from petroleum reservoirs. Other important parameter for surfactant flooding is an appropriate surfactant formula which is capable in mobilizing oil without significant surfactant losses due to phase separation in the reservoir (Bera et al., 2011). Surfactant must be able to be soluble in formation water (brine) to form a Type II microemulsion, where the surfactant is mainly in the oil phase, forming a water-in-oil micremulsions.

MES had been proven for lowering interfacial tension (IFT) of water-oil system until $10^{-3}$ dyne/cm but it has low solubility in formation water (brine), so it still could not be applied for surfactant flooding (Purwanto, 2006). However, the solubility of MES can be improved by adding emulsifier and secondary surfactant. Secondary surfactant must have Hydrophylic-Lipophylic Balance (HLB) number around 8, which issuitable for solubility rate of water-oil system (Kruglyakov, 2000). Hence, emulsifier with monomer organic compounds, polymer organic compounds or electrolyte also can be used to increase the solubility (Rosen, 2004).

Studies on surfactant formulation by adding emulsifier had been conducted. By adding $\mathrm{HCl}, \mathrm{MES}$ was tested to increase its solubility and decrease the IFT value. However, the addition caused the IFT value to increase (Lestari, 2006). Because of that, more research on the effect of emulsifier is still needed.

In industry, one of the most commonly used emulsifiers is Ethyl glycol monobutyl ether (EGBE) (Clark, 2004). Because it has high solubility in water formation, emulsification is easily obtained. It had also been observed that EGBE results in the lowering of IFT value (Purwanto, 2006). EGBE functions as organic compound that had hydrophobic chain that could lower the critical micelle concentration (CMC) (Rosen, 2004).

Other studies show that short-chain alcohol is effective in lowering IFT value. It changed the CMC by modifying the interaction of water with the surfactant molecule or with the micelle by modifying the structure of the water, its dielectric constant, or its solubility parameter (Rosen, 2004). Alcohol could decrease the potential of gel forming, lowering microemulsion viscosity and reducing potential of rich polymer phase separation on surfactant solution (Sheng, 2011).

This research uses a short-chain alcohol (ethanol $=\mathrm{A}$ ) and Ethyl Glycol Monobutyl Ether (EGBE = E) as emulsifier and Tergitol ( $\mathrm{T}$ ) as the secondary surfactant in the surfactant formulation process. Tergitol is used because it has HLB number around 9 which is soluble in water-oil system. It also has ethylene oxide group that can trigger forming process of ultra low interfacial tension area and lowering IFT value (Sheng, 2011). Ethylene oxide group can also influence the manner of surfactant solution such as CMC, aggregation number and distribution coefficient (Landry and Marangoni, 2008). EGBE and ethanol are used because it is considered that they have high solubility in water formation and effective in lowering IFT value. In addition, thermal stability was also considered. In surfactant stimulation process, surfactant can be contacted with high reservoir temperature in a long time period (Hu and Tuvell, 1988).

\section{Methodology}

At the beginning, brine water was made by mixing salt and water in certain composition. Initial surfactant formula was made by formulating MES, Tergitol, and emulsifier (ethanol or EGBE) in the specific percentages. Formulations containing MES, Tergitol, and ethanol were designated as 'MTA', and those containing MES, Tergitol, and EGBE as 'MTE'. Initial surfactant formula that had been made was added to brine to make surfactant-brine solution at several concentrations. Then, a drop of oil was added to each solution and the IFT values were measured by using a USA KINO TX-500C 
spinning drop tensiometer after its density had been measured by using Anton Paar DMA 4500 density meter. Density measurement of surfactant-brine solution was performed at $40{ }^{\circ} \mathrm{C}$.

The thermal stability test was done by heating surfactant-brine solutions which have ultra low interfacial tension $\left(10^{-3}\right.$ dyne $\left./ \mathrm{cm}\right)$ at $62.5^{\circ} \mathrm{C}$ for one day and seven days. After that, the IFT value of those solutions was remeasured.

Phase behaviour test was performed by observing the phase form of surfactant-brine solutions, which have ultra-low interfacial tension. The surfactant-brine solutions were introduced to beaker glass and its phases form were observed one day later (Tristantini et al., 2011).

\section{Results and Discussion}

\subsection{Concentration and Emulsifier Correlation}

IFT measurement was done to surfactant-brine solutions MTE (40:5:55); MTE (40:20:40); MTE (40:40:20); MTA (40:20:40) and MTA (40:40:20). Those solutions were measured at varying concentration from $0.1-5 \%$. Density measurement was done at $40{ }^{\circ} \mathrm{C}$ temperature to minimize complication effect that caused by particle precipitation at surfactant solutions (Binks et al., 2003).

Experiment results indicate that there is critical micelle concentration (CMC) value over all solutions that has been tested. There is a certain concentration value which has lowest IFT compared to others. IFT value is decreased because surfactant molecule is adsorbed in interfacial region of oil-water system (Bera et al., 2011). It is indicated by the concentration versus IFT graphic which had V shape (Tadros, 2002) in Figure 1 and 2.

CMC value is related to IFT value because the lowest IFT value will be achieved when concentration of surfactant is in CMC value. The tendency of CMC value appearance found overboth solutions that had been tested. However, CMC value is different one to another solution. It is indicating the effect of emulsifier difference to the CMC value of each of those solutions which can be observed on MTE(40:20:40) and MTA(40:20:40) solutions. MES fraction and Tergitol fraction from those two solutions are same with the different emulsifier. The CMC value of MT 40:20 E and MT 40:30 AK are different.

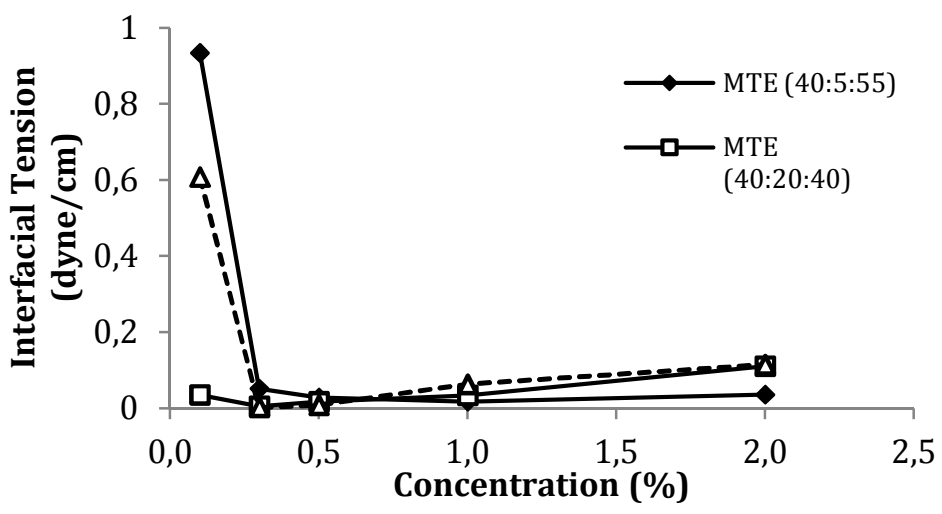

Figure 1. Concentration change of surfactant-brine solution in EGBE emulsifier toward IFT value change

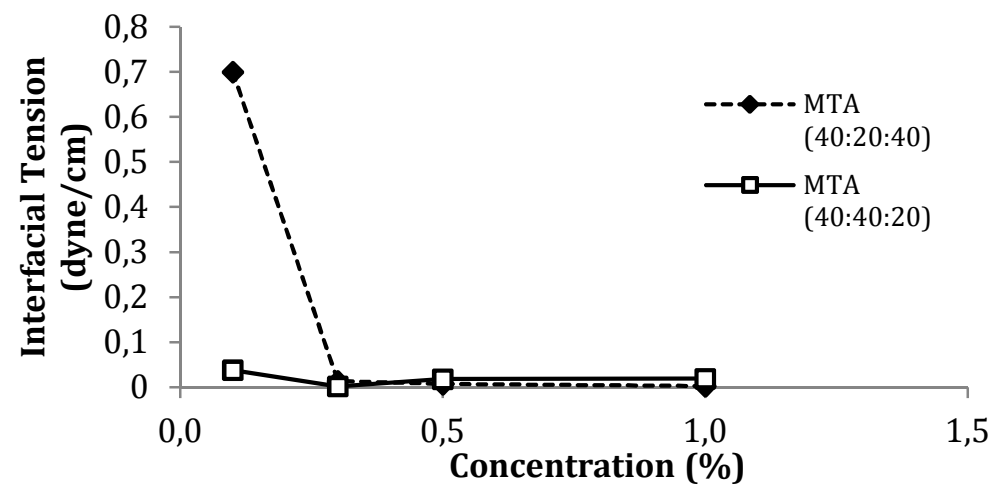

Figure 2. Concentration change of surfactant-brine solution in alcohol emulsifier toward IFT value change 
The difference of IFT value between surfactant-brine solutions with ethanol as emulsifier and surfactant-brine solutions with EGBE emulsifier is related to the emulsifier molecular structure. It causes different interaction between each emulsifier molecule with surfactant micelle as seen in Figure 3 and 4. Ethanol is a short chain alcohol which tends to be adsorbed on the hydrophilic surface of micelle. Adsorption which had been occurred in outer surface of micelle (hydrophilic portion) is decreased to form micelle, but not so much. Because of that, ethanol only gives a little effect in lowering the CMC value of solution (Rosen, 2004).

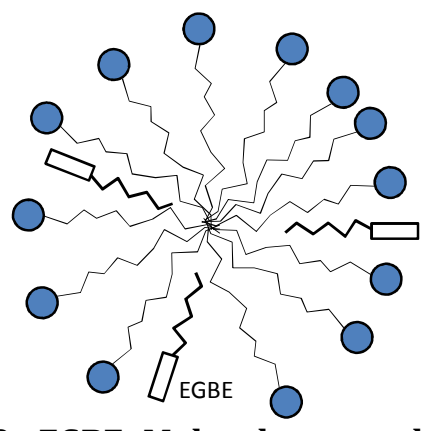

Figure 3. EGBE Molecule around Micelle (Rosen, 2004)

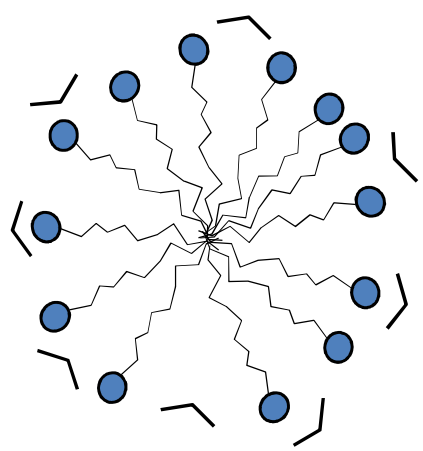

Figure 4. Ethanol Molecule around Micelle (Rosen, 2004)

EGBE molecule has a longer hydrophobic chain than alcohol. It can be adsorbed into micelle and be a small portion of micelle, so that causes a hydrophobic interaction between EGBE and micelle hydrophobic chains. Hydrophobic interaction can decrease the repulsion between hydrophilic heads because the distance between those heads increases, so the load charge on micelles is decreased (Rosen, 2004). This causes Gibbs energy of electrostatic repulsion between each hydrophilic heads decreases in a large amount and micellization process is easier to occur
(Graciani et al., 2010). For the same reason, EGBE has a bigger tendency than ethanol in lowering the $\mathrm{CMC}$ value.

\subsection{Thermal stability and IFT values correlation}

Thermal stability test was done on the formulations from each type of emulsifier blend that have ultra-low IFT, by varying their concentrations at three levels: MTA(40:20:40) at $0.5 \% ; 1 \% ; 2 \%$ and MTE(40:20:40) at $0.1 \%$; $0.3 \% ; 0.5 \%$. The results indicated that the IFT value of each solution tends to increase when it had been heated for one day and seven days, as shown in Figure 5 and 6. Longer heating period results in higher increase of IFT value. The IFT value is increasedwhen it had been heated for 1 and 7 days because the concentration becomes lower than CMC. Surfactant-brine solutions with concentrations higher than CMC indicate opposite phenomenon because the IFT value is decreased when it had been heated. It indicates the heating process increases CMC value of solutions.

The tendency of increased IFT value when they were heated is caused by decreasing solubility rate of emulsifier in water. It is happened because the hydrogen bond between water and organic emulsifier molecule is broken. The heating effect of changing CMC value is a complicated phenomenon since it is a combination between hydration effects of hydrophilic group and disturbance of water molecule structure around hydrophobic group. Hydration effect caused by hydrophilic group, triggers micellization process and in the other hand the disturbance of water molecule structure around hydrophobic groups hampers micellization process (Rosen, 2004). The increased temperature forms hydration effect on surfactant head group, so the surfactant solution entropy is decreased. It also becomes the reason of the decreased micellization rate (Batigoc et al., 2011).

CMC value of all surfactant-brine solutions increases although they are in different emulsifier. Heating causes the breaking of EGBE molecule, so CMC value is increasing and IFT value is changing. The increased temperature also makes surfactant molecules move faster on the interface region between oil and water. It decreases IFT value of the solution (Ruiz et al., 2003). 


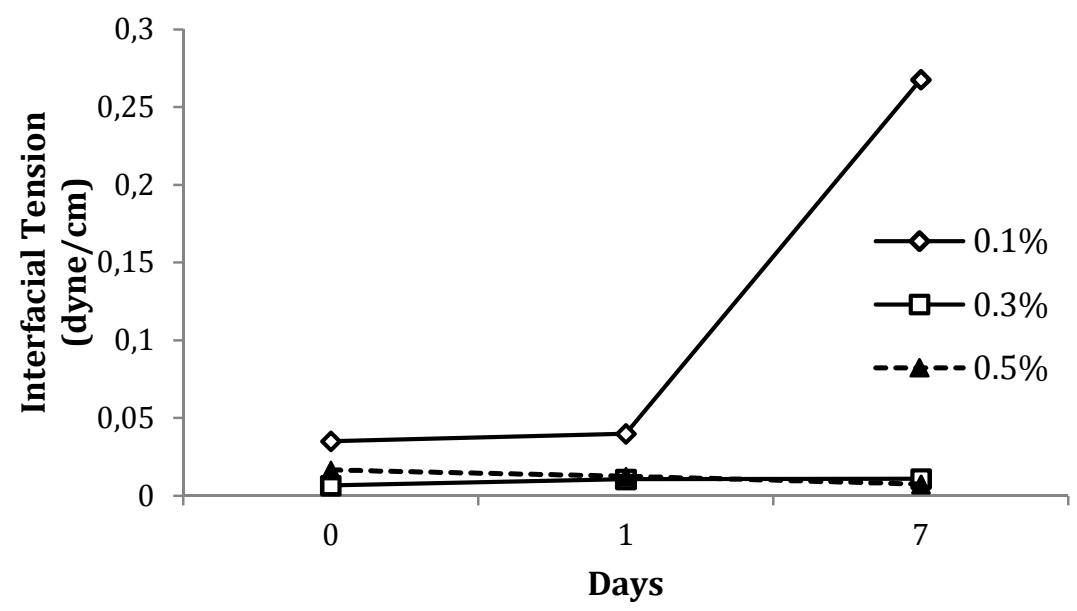

Figure5. IFT value change of MTE(40:20:40) $0.1 \% ; 0.3 \%$ and $0.5 \%$ solution after heating process

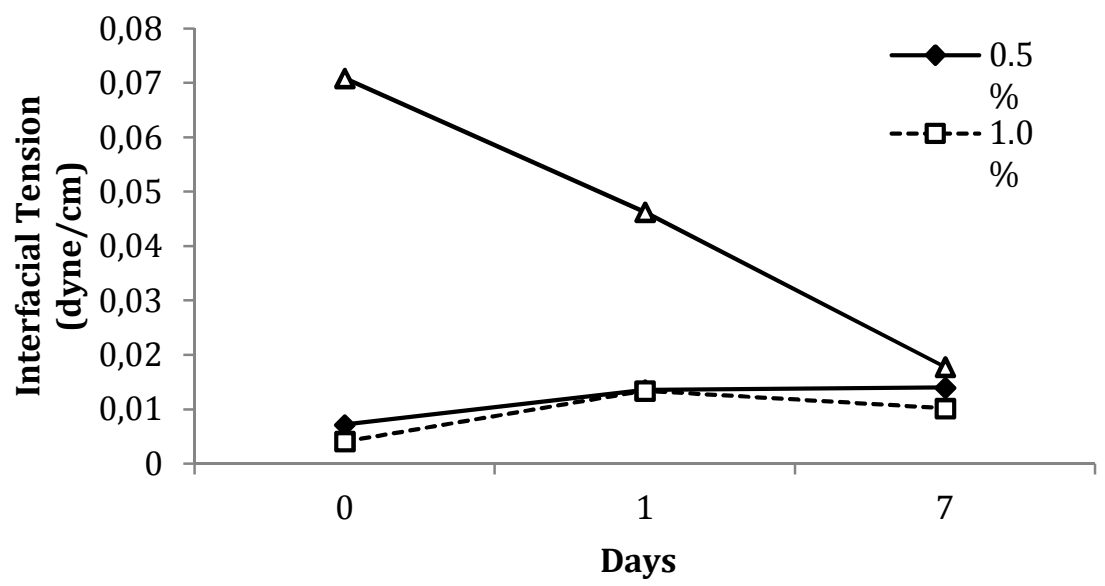

Figure 6. IFT value change of MTA(40:20:40) 0.5\%; 1\% and 2\%after heating process

\subsection{Compatibility (Solubility) Test}

Surfactant-brine solutions, with the IFT value as low as $10^{-3}$ dyne/cm, have a good solubility. They did not form two phases, as can be seen in Figure 7. By this result, the surfactant can form Type II microemulsion as one of criteria for EOR.

Alcohol can prevent gel forming in surfactant solution and micelle rich phase separation. Alcohol is also able to stabilize microemulsion that is indicated by the phase behavior of solution. It does not change and dissolves sulfonate-rich micelles (Sheng, 2011). In other hand, EGBE increases the solubility because it is a long chain polar compound. EGBE hydrophobic chain increases the solubility of other polar compound that is present in solution (Rosen, 2004).
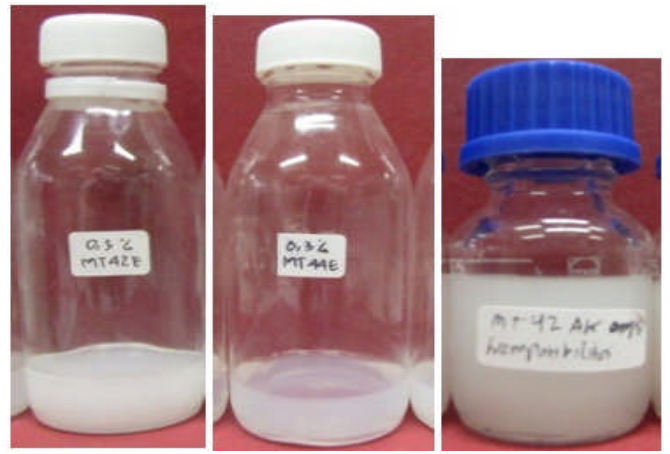

Figure 7. Phase Behavior of MTE (40:20:40) 0.3\%; MTE (40:40:20) 0.3\%; and MTA (40:20:40) 1\%

\section{Conclusion}

The improvement of MES as a surfactant in chemical flooding EOR has been studied. MES itself had low IFT value as low as $10^{-3}$ dyne $/ \mathrm{cm}$. However, its low solubility in brine waterstill needed further upgrading, so 
modification of MES was done by adding emulsifier.The emulsifier addition resulted in low IFT value and good solubility in brine water. The best formula in this research is MTE(40:20:40) $0.3 \%$ because its IFT value could reach $10^{-3}$ dyne/cm. In addition, when EGBE was compared to alcohol (ethanol), it gave better result. The optimal concentration of surfactant in EGBE addition case was $0.3 \%$, but when alcohol was used, the optimal concentration of surfactant was $1 \%$. It was because of the different structure (carbon chains) of emulsifier. These chains affected the micellar interactions formed. Besides, the thermal effect caused lower IFT up to a certain value for increasing interaction between emulsifier and micelle. Nevertheless, when the surfactant was over heated, the emulsifier structure collapsed and more interaction was difficult to be built and finally IFT value failed to decrease. The compatibility test showed positive result because the mixed surfactant only formed one phase since the emulsifier took part in increasing solubility. By these results, one of the requirements of surfactant used for EOR had been fulfilled. The surfactant had been proven with its low IFT value and high solubility. However, research is still needed for fixing the thermal problem.

\section{Acknowledgements}

Research and Development Center for Oil and Gas Technology (Lemigas) is gratefully acknowledged for the instruments and financial support.

\section{References}

Batigoc, C.; Akbas, H.; Boz, M., Micellization behaviour and thermodynamic parameters of 12-2-12 gemini surfactant in (water + organic solvent) mixtures, The Journal of Chemical Thermodynamics, 2011, 43(9), 1349-1354.

Bera, A.; Ojha, K.; Mandal, A.; Kumar, T., Interfacial tension and phase behaviour od surfactant-brine-oil system, Colloids and Surfaces A: Physicochemical and Engineering Aspects, 2011, 383(1-3), 114-119.

Binks, B. P.; Espert, A.; Fletcher, P. D. I.; Soubiran, L., Phase behaviour of microemulsion stabilised by double chain cationic surfactants and alcohol co-surfactant, Colloids and Surfaces A: Physicochemical Engineering Aspects, 2003, 212(2-3), 135-145.
Clark, J., Dispersant Basics: Mechanism, Chemistry, and Physics of Dispersants in Oil Spill Response, Presentation to NRC Committee on Understanding Oil Spill Dispersant: Efficacy and Effects, 15 March 2004.

Graciani, M. D. M.; Rodriguez, A.; Martin, V. I.; Moya, M. L., Micellization and micellar growth of alkanediyl- $\quad \alpha, \omega$-bis(dimethyldodecyl ammonium bromide) surfactants in the presence of medium-chain linear alcohols, Journal of Colloid and Interface Science, 2010, 342(2), 382-391.

Hambali, E.; Permadi, P.; Pratomo, A.; Suryani, A.; Maria, R., Palm oil-based methyl ester sulphonate as an oil well stimulation agent, Journal of Oil Palm Research, 2008, Special Issue, 8-11.

Hu, P. C.; Tuvell, M. E., A mechanistic approach to the thermal degradation of $\alpha$-olefin sulfonates, Journal of the American Oil Chemist's Society, 1988, 65(6), 1007-1012.

Kruglyakov, P. M., Hydrophile-Lipophile Balance of Surfactants and Solid Particles; Elsevier Science: Amsterdam, 2000; pp. 153244.

Landry, J. M.; Marangoni, D. G., The effect of added alcohol in the micellization process of sodium 8-phenyloctane, Colloid Polymer Science, 2008, 286(6-7), 655-662.

Lestari, A., Kajian Pengaruh Suhu, Lama Pemanasan, dan Konsentrasi Asam (HCl) terhadap Kemampuan Surfaktan Metil Ester Sulfonat (MES) Sebagai Oil Well Stimulation Agent, Bachelor final project, Institut Pertanian Bogor, 2006.

Purwanto, S., Penggunaan Surfaktan Metil Ester Sulfonat Dalam Formula Agen Pendesak Minyak Bumi, Bachelor final project, Institut Pertanian Bogor, 2006.

Rosen, M. J.; Surfactant and Interfacial Phenomena; John Wiley \& Sons: New Jersey, 2004; pp.105-167.

Ruiz, C. C.; Molina-Bolivar, J. A.; Aguiar, J.; MacIsaac, G.; Moroze, S.; Palepu, R., Effect of ethylene glycol on the thermodynamic and 
micellar properties of Tween 20, Colloid Polymer Science, 2003, 281(6), 531-541.

Sheng, J. J., Modern Chemical Enhanced Oil Recovery: Theory and Practice; Gulf Professional Publishing-Elsevier: Burlington, 2011; pp. 254-291.

Tadros, T. F., Surfactants, Industrial Application. in Encyclopedia of Physical
Science and Technology; Meyers, R. A., Ed.; Academic Press: Massachussets, 2002; pp. 423-438.

Tristantini, D.; Halim, H. P.; Zuliardy, M. F., The Effect of Emulsifier to Methyl Ester Sulfonat Performance as Chemical Flooding Material, Proceeding of International Seminar on Chemical Engineering Soehadi Reksowardojo 2011, Bandung, 5-7 October 2011. 